\section{Rate $\quad$ No. of}

III. Repurchase permitted if 10 capital is not impaired.
IV. Repurchase permitted out of "surplus" only (with varying definitions of "surplus").

V. Repurchase permitted if sufficient assets remain to pay corporate debts.

VI. Repurchase permitted only as provided for in detailed statutes setting out limited specific uses of repurchase.

VII. No pertinent statutory or case law.
ARE. St.IT. ANN. \$64-109(e) (1947); Fla. Stat. AnN. tit. 34, \& 612.0S(3) (1943); MiNk. Stat. ANv. $\$ 301.22(6)$ (1916); N.Y. PENaL. LAW $\S 664(5) ;$ N. DAK. REV. CODE \& 100323 (1943); OkLA. Stat. Asw. tit. 18, $\$ 1.136$ (Supp. 1949); ORE. CONR. L. ANR: $\$ 77-238 \mathrm{C}$ (Supp. 1947); S.D. CODE $\$ 11.0303$ (1939); TENN. CODE ANN. \$3722(9) (NVilliams, 1934).

2 Mo. Rev. Stat. ANs. c. 33, $\$ 4997.13$ (Supp. 1949); Neb. Rev. Stat. c. 21,8153 (1943).

Cal. Corp. Code ANw. $\$ 1705-1707$ (Deering, 1947); CoNN. GEN. STAT. tit. 39, c. 250, $\S 5181$ (1949); Surth-HuRd IlL. ANzi. Stat. c. 32, \&157.6 (Supp. 1949); KAN. GEN. STAT. §17-3004 (Supp. 1947); LA. Gen. Stat. ANw. $\$ 1103$ (Dart, 1939); 11D. ANiv. CodE art. 23, $\$ 54$ (1939); Orro GEN. CODE ANN. \$ 8623-41 (Page, Supp. 1949).

Idaho, Mississippi, New Mexico, South Carolina and Wyoming.

\title{
SECTION 2255 OF THE JUDICIAL CODE: THE THREATENED DEMISE OF HABEAS CORPUS*
}

THE quickest way for a prisoner to test the validity of his confinement is to petition a court for a writ of habeas corpus. Unfortunately, prisoners have often abused this traditional remedy ${ }^{1}$ by assailing courts with ground-

* Barrett v. Hunter, 1S0 F.2d 510 (10th Cir. 1950).

1. The exact origin of the habeas writ is open to dispute. See Jenls, The Story of the Habeas Corpus, 18 L.Q. Rev. 64 (1902); Note, 61 HARv. L. Rev. 657 (1948). For extended treatment tracing its development from the Mfagna Carta see Cohen, Some Considerations on the Origins of Habeas Corpus, 16 CAw. B. Rew. 92 (1938); Cohen. Habeas Corpus Cum Causa-The Energence of the Modern Writ, 18 CArr. B. Rew. 10 (1940). 
less petitions. ${ }^{2}$ In order to minimize such abuse by federal prisoners, Congress enacted Section 2255 of the new Judicial Code ${ }^{3}$ which virtually replaces habeas corpus as the prisoner's chief hope of freedom.

Section 2255 permits a prisoner to bring a motion in the sentencing court ${ }^{4}$ to have his sentence set aside or corrected. Unless the motion and the trial records conclusively show that relief is not justified, the court is required to grant a "prompt" hearing. The grounds for relief under the motion are substantially the same as under habeas corpus. ${ }^{5}$

Although the substantive standards for granting relief are the same, Sec-

2. See Goodman, Use and Abuse of the Writ of Habeas Corpus, 7 F.R.D. 313 (1948); Parker, Limiting the Abuse of Habeas Corpus, 8 F.R.D. 171 (1949).

This excessive use of habeas in the district courts is of recent origin. In 1937, 295 petitions were brought by federal prisoners, 174 by state prisoners. ANNuAt Reroltr of the Director of the Administrative Office of tre United States Courts 71 (1940). By 1948 these figures had increased to 506 and 543 respectively. Speck, Statistics on Federal Habeas Corpus, 10 Onio St. L.J. 337, 341 (1949).

The increase is generally attributed to a series of pre-1943 Supreme Court decisions which liberalized the scope of the writ and the procedural requirements for its issuance. As a result of these decisions, habeas can be used to attack any conviction which has violated the "constitutional rights of the accused." See, e.g., Waley v. Johnston, 316 U.S. 101, 105 (1942) (coerced guilty plea); Johnson v. Zerbst, 304 U.S. 458 (1938) (denial of counsel); Mooney v. Holohan, 294 U.S. 103 (1935) (perjurcd testimony). Unless the records refute the prisoner's allegations, courts must issue the writ and hold a hearing even though the prisoner's claims seem incredible. Waley v. Johuston, supra. For discussions of these expansions see Holtzoff, Collateral Revicw of Convictions in Federal Courts, 25 B.U.L. Rev. 26 (1945); Note, 61 HaRv. L. Rev. 657 (1948).

3. 28 U.S.C. $\$ 2255$ (Supp. 1950).

The section originally was proposed by the Judicial Conference of Senior Circuit Judges which had appointed a committee in 1942 to study the problem. REPORT of THE Judicial Conference 18 (September Session 1942). For a history of the section see United States v. Calp, 83 F. Supp. 152, 153 (D. Md. 1949). As adopted by Congress, $\$ 2255$ substantially follows the recommendations of the Conference.

Abuse of habeas by state prisoners is dealt with in $\$ 2254$. The section requires that all state remedies be exhausted before a prisoner can apply for relief in the federal courts. See Ex parte Hawk, 321 U.S. 114 (1944); Note, 59 YALE L.J. 806 n.27 (1950). The Supreme Court recently interpreted the exhaustion rule to require that a prisoner petition for certiorari from the state supreme court unless "special circumstances" exist. Darr v. Burford, 18 U.S.L. WeEK 4217 (U.S. April 3, 1950).

4. In this respect, the motion is similar to the common law writ of error coram nobis which is brought in a sentencing court to vacate a judgment. Sec Reviser's Note, 28 U.S.C. $\$ 2255$ (Supp. 1950). For a discussion of the relation between $\$ 2255$ and coram nobis, indicating that the section has not replaced the old writ in federal courts, see Note, 59 Yale L.J. 786 (1950).

5. James v. United States, 175 F.2d 769 (5th Cir. 1949) ; United States v. Meycrs, 84 F. Supp. 766 (D.D.C. 1949).

The motion is authorized where the prisoner alleges that "the sentence was imposed in violation of the Constitution or laws of the United States, or that the court was without jurisdiction to impose such sentence, or that the sentence was in excess of the maximum authorized by law, or is otherwise subject to collateral attack." 28 U.S.C. \$2255 (Supp. 1950). See the discussion of the grounds for habeas corpus in note 2 supra. 
tion 2255 differs from habeas in three important procedural respects. First, habeas may be sought in the jurisdiction of confinement, ${ }^{\circ}$ while the motion under Section 2255 must be brought in the sentencing court. Undoubtedly, the drafters felt that trial records should be available to refute spurious claims. ${ }^{7}$ Second, while a hearing must be held, the court at its discretion may hold it without the prisoner-a basic departure from habeas procedure. Third, there is a definite time limit imposed on the court and wardens in habeas proceedings, ${ }^{8}$ while the only time requirement of Section 2255 is promptness. Despite these differences, however, the section provides that courts may no longer entertain the habeas petitions of federal prisoners unless the motion procedure is deemed "inadequate or ineffective" to test the validity of confinement. ${ }^{9}$

Although the section was designed as a substitute for habeas corpus, the number of habeas petitions brought by federal prisoners has not declined. ${ }^{10}$

6. A district court's power to grant the habeas writ is limited to the confines of its respective district. 28 U.S.C. \$2241 (a) (Supp. 1950); Alrens v. Clark, 335 U.S. 188 (1948), 47 MIcr. L. Rev. 128; Jones v. Biddle, 131 F.2d 853 (Sth Cir. 1942), ecrt. denicd, 318 U.S. 784 (1943). But cf. Ex parte Endo, 323 U.S. 283 (1944) (writ is permissible where prisoner is removed to another district while the proceedings are pending). While the jurisdiction of the district courts extends to hearing petitions from state prisoners, state courts may not hear petitions from federal prisoners. Robb v. Connolly, 111 U.S. 624 (1884) ; Ableman v. Booth. 21 How. 506 (U.S. 1858).

7. See Parker, Limiting the Abuse of Habeas Corpus, 8 F.R.D. 171, 175 (1949). Judge Parker was chairman of the Judicial Conference committee which recommended adoption of $\S 2255$.

8. See page 1188 infra.

9. The Section provides: "An application for a writ of habeas corpus in behalf of a prisoner who is authorized to apply for relief by motion pursuant to this section, shall not be entertained if it appears that the applicant has failed to apply for relief, by motion to the court which sentenced him, or that such court has denied him relief, unless it also appears that the remedy by motion is inadequate or ineffective to test the legality of his detention." 28 U.S.C. \$2255 (Supp. 1950).

Since $\$ 2255$ only applies to prisoners sentenced by federal courts, habeas may still be used to attack court-martial convictions or administrative orders. Massey v. Humphrey, 85 F. Supp. 534 (M.D. Pa. 1949) (court-martial); United States cx rel. De Lucia v. O'Donovan, 82 F. Supp. 435 (N.D. Ill. 1948) (parole board order).

10. Section 2255 became effective on September 1, 1948. Nevertheless, from July 1, 1948 to June 30, 1949, 477 habeas corpus petitions were filed in the district courts by federal prisoners. Speck, Statistics on Fedcral Habcas Corpus, 10 Omı St. L.J. 337, 341. (1949). And 233 petitions were filed in the last six months of 1949-the same number brought during that period in 1948. Quarterly Report of tIIE DiRectos of tine Adainistrative Office of the Uxited States Cocrets, Table C2 (1950). There has, however, been a slight decline in applications brought in Kansas and in the southern districts of New York, Indiana, and California. Communication to the Yale LAw JounNaL from W. S. Speck, Att'y, Administrative Office of the United States Courts, dated February 10, 1950, in Yale Law Library.

At the same time prisoners are not using the motion to any great extent. Only 102 motions were filed from September 1, 1948 to June 30, 1949, and 63 during the last six months of 1949. Ibid. 
But most of these petitions, whether brought before the motion or after its denial, have been dismissed. ${ }^{11}$ The position taken by a large majority of the courts is exemplified by a recent decision of the Tenth Circuit Court of Appeals in Barrett v. Hunter. ${ }^{12}$ Petitioner, confined in Leavenworth, Kansas, applied for release under Section 2255 in a federal district court in Texas, alleging that he had been held incommunicado before trial and had been denied counsel. Without advancing any reasons for its decision, the Texas court dismissed the motion. The prisoner then petitioned for habeas corpus in the District Court of Kansas, alleging that the motion was an inadequate remedy. His petition was denied on the ground that he had failed to prove inadequacy of the motion. In affirming this decision, the court of appeals decided that the motion, where adequate, completely replaced habeas. Nevertheless, it held that Section 2255 did not contravene the constitutional prohibition against suspending the habeas writ. ${ }^{13}$

Although some courts have expressed the view that the motion is merely a prerequisite to the use of habeas, ${ }^{14}$ the Barrett holding that it is an exclusive remedy finds complete justification in the language of the statute. ${ }^{1 "}$ And when the section is viewed abstractly, the court's affirmation of constitutionality is similarly warranted. ${ }^{16}$ The section's saving feature is its nebulous ${ }^{17}$ "inadequate or ineffective" clause: since federal prisoners may

11. Since the enactment of $\$ 2255$, there have been only three reported decisions in which habeas was granted to federal prisoners authorized to use the motion. Sce Mugavero v. Swope, 86 F. Supp. 45 (N.D. Cal. 1949) (granted before the motion was tried); Stidham v. Swope, 82 F. Supp. 931 (D. Cal. 1949) (same); St. Clair v. Hiatt, 83 F. Supp. 585 (N.D. Ga. 1949) (granted after motion denied).

Most habeas petitions are brought before the motion is tried and are dismissed summarily: the prisoner is told to seek relief by motion first. E.g., Cline v. Hiatt, $174 \mathrm{~F} .2 \mathrm{~d}$ 822 (5th Cir. 1949); McGough v. Hiatt, 174 F.2d 353 (5th Cir. 1949).

12. 180 F.2d 510 (10th Cir. 1950). Judge Huxman dissented.

13. "The Privilege of the Writ of Habeas Corpus shall not be suspended, unless when in Cases of Rebellion or Invasion the public Safety may require it." U.S. CoNST. Art. I, §9.

The issue of suspension of habeas corpus has arisen only twice in this countryduring the Civil War and in Hawaii during World War II. See Fairman, The Law of Martial Rule and the National Emergency, 55 HARv. L. Rev. 1253 (1942); Smith, Martial Law and the Writ of Habeas Corpis, 30 Geo. L.J. 697 (1942).

14. E.g., St. Clair v. Hiatt, 83 F. Supp 585 (N.D. Ga. 1949); Stidham v. Swope, 82 F. Supp. 931 (D. Cal. 1949) ; Wong v. Vogel, 80 F. Supp. 723 (E.D. Ky. 1948). Scc Barrett v. Hunter, 180 F.2d 510, 516 (10th Cir. 1950) (dissenting opinion). Bult sec Taylor v. United States, 177 F.2d 194 (4th Cir. 1949).

15. See note 9 stupra. But see St. Clair v. Hiatt, 83 F. Supp. 585 (N.D. Ga. 1949) (habeas petition granted after motion denied).

16. The section's constitutionality has also been upheld by several other courts. E.g., Martin v. Hiatt, 174 F.2d 350 (5th Cir. 1949); Wong v. Vogel, 80 F. Supp. 723 (E.D. Ky. 1948).

17. There is no legislative history indicating under which circumstances the motion is inadequate. However, the section as phrased by the Conference of Senior Circuit Judges in recommending it does shed some light on this point. The Conference report 
still use habeas when the motion is inadequate, theoretically the writ has not been suspended.

But abstract constitutionality is not sufficient. If the motion is to replace habeas in any given case, it must provide an equivalent remedy or the writ, in effect, will be suspended. But Section 2255 does not provide a substantial equivalent. The habeas provisions in the Judicial Code permit the prisoner to testify whenever issues of fact are presented. ${ }^{18}$ Section 2255 , on the other hand, gives the trial court complete discretion to hold a hearing without calling the prisoner. ${ }^{19}$ Transportation difficulties militate against the

suggested that habeas be granted to a prisoner if "it appears that it has not been or will not be practicable to have his right to discharge from custody determined on such motion because of the necessity of his presence at the hearing, or for other reasons." REpost of the Judiclal Conference 24 (September Session 1943).

Only two courts have so far found the motion inadequate and granted a writ of habeas corpus. One based its finding on the fact that the sentencing court was situated far from the prison. Stidham v. Swope, 82 F. Supp. 931 (D. Cal. 1949) (confinement in California, sentence in Missouri). In the other case the petitioner's co-defendant had asked the trial court to reduce his sentence on the ground that it was excessive. This motion was denied. The habeas court felt that the sentence should have been reduced and granted the writ to the petitioner on the ground that the motion's adequacy "depends to a large extent upon our conclusions as to the substantive merits of the petitioner's ease." Mugavero v. Swope, 86 F. Supp. 45, 46 (N.D. Cal. 1949).

18. 28 U.S.C. $\$ 2243$ (Supp. 1950); Walker v. Johnston, 312 U.S. 275 (1941). Before its inclusion in the Code, this requirement was based on the Supreme Court's interpretation of the former habeas statute. See Walker v. Johnston, sipro. Issues of law may be decided in the prisoner's absence.

19. 28 U.S.C. $\$ 2255$ (Supp. 1950). This is accepted practice under writs of error coram nobis. See Carman v. State, 208 Ind. 297, 196 N.E. 78 (1935).

Cognizant of the section's weakness in this respect, the court of appeals, in the Barrett case, denied that district courts have absolute discretion to hold hearings in the prisoner's absence. It felt that where "material and substantial issues of fact" are raised, "in the exercise of a sound discretion, the court should require the production of the prisoner." 180 F.2d 510, 514. But other courts have not been so benign. See, e.g., Crowe v. United States, 175 F.2d 799, 801 (4th Cir. 1949) (production of prisoner necessary "only in very rare cases").

Although the Supreme Court has never held that it is a denial of due process to conduct a hearing without the prisoner, there have been some dicta to that effeet in lower court opinions. See, c.g., Ex parte Rosier, 133 F.2d 316, 325 (D.C. Cir. 1942). United States $\approx$. Landicho is illustrative. There the prisoner, confined in Washington, applied for relief by motion in the nature of coram nobis, in the sentencing court at Archorage, Alaska. That court dismissed the motion, stating: "II]t may" be noted that in the present instance ... a petition for writ of habeas corpus . . . can probsbly be heard and determined more expeditiously and economically, and with surer protection for the rights of the defendant, than a full hearing in this court on the defendant's motion. Despite the suggestion that the absence of the defendant on such a hearing involves no deprivation of any constitutional right, ... it appears that the inherent requirements of a fair trial would demand that the defendant for such a hearing be brought from his prison to the headquarters of this court. ... Putting aside all directions of statute and rule it may well be asked whether due process can be satisfied with less." 72 F. Supp. 425,429 (D. Alaska 1947). 
prisoner's being called when he is far from the trial court. And even when he is, near, there is no assurance that he will be allowed to testify. Indeed most hearings under the section have been held without the prisoner. ${ }^{20} \mathrm{He}$ is therefore forced to support his plea by affidavit, ${ }^{21}$ while the government may have the advantage of contesting the motion orally. Moreover, when the prisoner is not called, counsel is usually not appointed for him. ${ }^{22}$ And where a lawyer is designated for a distant prisoner, he may not be able to learn the full facts of the case since all his information must be gleaned from correspondence with his client.

In addition, even if the prisoner is called to a hearing, the motion may be more time-consuming than the summary habeas procedure. Under habeas provisions in the Code, courts are required to issue the writ "forthwith"; wardens are required to file returns in three days unless additional time is granted; and hearings must start within five days. ${ }^{23}$ In contrast, Section 2255 places no time limit on the preliminary steps. Thus, where a prisoner is called, there is no assurance that his motion will receive immediate disposition. This is true even if he is confined near the trial court; and when he is brought from a remote penitentiary, greater delay can be expected. ${ }^{24}$

In view of the motion's deficiencies, the "inadequate or ineffective" clause of Section 2255 should be applied liberally. Courts should grant a subsequent habeas petition whenever factual issues are raised in the motion and the prisoner is not called, ${ }^{25}$ since in these circumstances the motion, by

20. From September 1, 1948 to June 30, 1949, 102 motions were filed. Statistics for 76 of these motions indicate that 12 prisoners were present at a hearing. Speck, Statistics on Federal Habeas Corpus, 10 Oнго Sr. L.J. 337, 358 (1949).

21. See United States v. Calp, 83 F. Supp. 152 (D. Md. 1949).

22. From September 1, 1948 to June 30, 1949, 102 motions were filed. Statistics for 76 of these motions indicate that only 29 prisoners were represented by counsel. Speck, supra note 20 , at 358 . Although it is uniformly held that a prisoner, petitioning for habeas, does not have a constitutional right to be aided by counsel, federal courts often appoint counsel when a prisoner is impecunious. See Note, 15 U. of CHr. I. REv. 945 (1948).

23. 28 U.S.C. $\$ 2243$ (Supp. 1950). The rigid time requirement for habeas procedure has remained substantially unchanged since the English Habeas Corpus Act of 1679. See Cohen, Habeas Corpus Cum Causa-The Emergence of the Modern WritII, 18 CAN. B. REv. 172, 187 (1940).

24. The section may also be inadequate in its treatment of successive applications: courts are granted full discretion to reject second or successive petitions for "similar relief." See Moss v. United States, 177 F.2d 438 (10th Cir. 1949). It is not clear what "similar relief" means. Under the section courts may grant three different types of relief: they may set aside, vacate, or reduce a sentence. Thus, for example, where a prisoner's first motion asked for vacation of sentence and his second asks for correction of sentence, he apparently will be heard. But if the same "relief" is requested, apparently the court may reject a second motion even though new grounds are alleged.

The modified res judicata rule applied to habeas petitions is more favorable to the prisoner. See note 31 infra.

25. The Barrett case was complicated by the fact that the Texas district court had not stated its reasons for denying the petitioner's motion. The habeas court did not know, 
allowing an ex parte hearing, is almost certainly an "inadequate or ineffective" remedy. But granting habeas after the motion has been used is not alone sufficient. By compelling the prisoner to try his luck with the motion first, the courts will have destroyed the speed which is an essential feature of habeas. The writ should therefore be granted beforehand. Although this may nullify Section $2255,{ }^{26}$ it is the only way in which a prisoner's rights can be adequately protected while the section is in force.

The most appropriate treatment for the section is repeal.77 Its proponents argue that it is needed to limit the abusive practices which prevailed before its adoption. ${ }^{28}$ But the habeas provisions now in the Code furnish sufficient safeguards against abuse without the additional severity of Section 2255. Wardens are now compelled to attach copies of the indictment, plea, and judgment ${ }^{29}$ to habeas returns or to orders requiring them to show cause why the writ should not issue. By using this show cause procedure more frequently, with these records before it, the court can weed out most spurious claims before issuing the writ. ${ }^{\text {so }}$ In addition, courts may now use a modified res judicata rule to reject successive petitions based on similar grounds. ${ }^{32}$

therefore, whether or not the prisoner's allegations were refuted in the trial records. To avoid such ambiguity, courts should clearly state their grounds for denying a $\$ 2255 \mathrm{mo}$ tion. In addition, where factual issues not covered in the record are presented and the prisoner is not called to testify, courts might state that denial of the motion is without prejudice as to those issues. The prisoner could then be heard on those issues by petitioning for habeas.

26. The section would still be effective where a prisoner voluntarily sought relief by motion before trying habeas and was called to a hearing. Under such circumstances, it would be useless for the habeas court to grant the writ.

27. Of course the section could be amended to permit a prisoner to testify whenever the motion raises factual issues not covered by the record. But where prisoners are located far from the trial court, transportation difficulties make this impractical. Mroreover, it would frequently be impossible to call such prisoners and at the same time achieve a summary procedure.

28. See Parker, Limiting the Abuse of Habcas Corpns, \& F.R.D. 171 (1949).

29. 28 U.S.C. $\$ 2249$ (Supp. 1950). While these may not be as complete as the records available at the trial court, they should prove adequate for most cases. Of course not even the trial records will be helpful where the petitioner alleges, for example, that his guilty plea was forced or that perjured testimony was used against him.

30. See Walker v. Johnston, 312 U.S. 275, 284 (1941). Practice among the district courts has varied. The Washington district usually disposes of petitions on a show cause hearing, while Georgia always issues the writ to bring the prisoner into court. Speck, Statistics osr Fcderal Habcas Corpus, 10 Onıо St. L.J. 337, 339 (1949). Of course, the show cause procedure can be used exclusively only when issues of law are raised. If questions of fact not covered by the record are presented, the writ must issue, bringing the prisoner into court to testify. 28 U.S.C. $\$ 2243$ (Supp. 1950); Walker v. Jolnston, supra.

Until the new Code there was no express statutory authorization for the show cause procedure. See discussion of its origin in Longsdorf, Habeas Corpus-A Profcan Writ and Remedy, 8 F.R.D. 179, 187 (1948).

31. District courts are not required to hear a petition if (1) a previous one has been denied, (2) no new ground is presented, and (3) the court is satisfied that the "ends of 
If these measures are insufficient, perhaps special habeas courts might be created in districts containing major federal prisons. ${ }^{32}$

The quest for more efficient administration should not override a prisoner's opportunity to attack a questionable conviction. Even if some prisoners did abuse the habeas writ, the solution does not lie in making it difficult for all prisoners seeking relief.

justice will not be served" by holding a hearing. 28 U.S.C. $\$ 2244$ (Supp. 1950). Sec MLORE's Judicial COdE 436 (1949).

32. Six districts handie a substantial number of the habeas petitions brought by federal prisoners. These are the Northern District of California, Northern District of Georgia, Kansas, Western District of Missouri, Western District of Washington, and the District of Columbia. In Georgia and Kansas, habeas trials represent a significant part of the courts' total work-26\% and $65 \%$ respectively. Speck, Statistics on Fcderal Habees Corpus, 10 Оніо Sт. L.J. 337, 350 (1949). 